\title{
Organization Culture and Quality Management System: A Systematic Literature
} Review

Rafael Augusto de Oliveira Sanches ${ }^{1}$, FUMEC University, Belo Horizonte, Minas Gerais, Brazil.

Eric de Paula Ferreira ${ }^{2}$, State University of Minas Gerais, Belo Horizonte, Minas Gerais, Brazil.

Fernando Silva Parreiras ${ }^{3}$, FUMEC University, Belo Horizonte, Minas Gerais, Brazil.

\section{RESUMO}

Objetivo - Visando suprir a necessidade de consolidação e análise crítica dos trabalhos elaborados acerca da Cultura Organizacional e dos Sistemas de Gestão da Qualidade, a pesquisa tem como objetivo compreender a relação entre esses conceitos por meio de uma revisão sistemática da literatura.

Desenho / metodologia / abordagem - A pesquisa é descritiva e se caracteriza, preponderantemente, por uma abordagem quantitativa. Por meio da técnica de revisão sistemática da literatura, foram analisadas publicações contidas nas bases Materials Science \& Engineering Database, Emerald Insight, OneFile (GALE), Taylor \& Francis Online Journals, ScienceDirect Journals (Elsevier), Elsevier (CrossRef), Directory of Open Access Journals (DOAJ), MEDLINE/PubMed (NLM), Library \& Information Science Collection e Springer (CrossRef) e recuperados 22 trabalhos que tratam dos temas de forma integrada.

Resultados - A análise demonstra que os modelos de Cameron e Quinn (2011) e Hofstede (2003) são os mais utilizados. No que tange aos setores empresariais nos quais as pesquisas foram realizadas, constatou-se que não foram identificadas pesquisas relacionadas aos temas pesquisados em empresas de utilities, sendo a maior parte dos estudos $(38 \%)$ realizada em companhias do setor industrial.

Originalidade / valor - No que diz respeito aos aspectos da gestão da qualidade relacionados à cultura organizacional, observa-se na literatura um equilíbrio entre as dimensões hard e soft e que a maioria das pesquisas apresenta como público alvo para a fonte de dados os níveis gerenciais das empresas.

Palavras-chave - Cultura Organizacional, Sistema de Gestão, Sistema de Gestão de Qualidade, Revisão Sistemática de Literatura.

\section{ABSTRACT}

Purpose - Aiming to fulfill the need to consolidate and carry out a critical analysis of the studies developed on Organizational Culture and Quality Management Systems, this study aims to understand the relationship between these concepts through a systematic review of the literature.

Design/methodology/approach - This study is descriptive and is predominantly classified as a quantitative approach. Using the systematic literature review technique, publications contained in the Materials Science \& Engineering Database, Emerald Insight, OneFile (GALE), Taylor \& Francis Online - Journals, ScienceDirect Journals (Elsevier), Elsevier (CrossRef), Directory of databases were analyzed Open Access Journals (DOAJ), MEDLINE / PubMed (NLM), Library \& Information Science Collection and Springer (CrossRef) and 22 studies that deal with the topics in an integrated manner were used.

Findings - The analysis shows that the Cameron and Quinn (2011) and Hofstede (2003) models are the most used. Regarding the business sectors in which studies were carried out, no research relating to the topics studied in utilities companies had been carried out, with most of the studies (38\%) carried out in companies in the industrial sector.

Originality/value - With regard to aspects of quality management relating to organizational culture, there is a balance between the hard and soft elements in the literature and that most studies put forward the management levels of companies as the target audience for the data source.

Keywords - Organizational Culture, Management System, Quality Management System, Systematic Literature Review.

1, rsanches@cemig.com.br, http://orcid.org/0000-0003-3080-4993; 2. Rodovia Papa João Paulo II, 4143, Ed. Minas, Cidade Administrativa Presidente Tancredo Neves, Bairro Serra Verde, Belo Horizonte, MG, CEP: 31.630-900, Brasil, eric.p.f@gmail.com, http://orcid.org/0000-0002-7513-501X; 3. fparreiras@liaise.tech, http://orcid.org/0000-0002-9832-1501.

SANCHES, R. A. O.; FERREIRA, E. P.; PARREIRAS, F.S. Organization Culture and Quality Management System: A

Systematic Literature Review. GEPROS. Gestão da Produção, Operações e Sistemas, v.16, nº 1, p. 150 - 180, 2021.

DOI: http://dx.doi.org/10.15675/gepros.v16i1.2700 


\section{INTRODUCTION}

Although there is acknowledgment on the need and the importance of quality management practices, inquiries regarding the significant costs and the obstacles to the implementation in some types of organization constantly arise. According to Fai Pun and Jaggernath-Furlonge (2012), many reported faults in the adoption of management practices are attributed to the use of techniques that are not in tune with the organization's culture.

To this end, the organizations need to comprehend how to implement their quality management systems in order to achieve greater benefits as using a standardized approach for all companies seems not to be the best strategy. Different organizations need specific management approaches (ZHANG; LINDERMAN; SCHROEDER, 2012).

According to Irani, Beskese and Love (2004), many researchers claim that Total Quality is in some way linked to organizational culture. The expression "Total Quality Culture" has been frequently used in the literature. Many companies that carry out Total Quality programs have turned their attention to the application of quality tools and techniques, seeking to align their programs with the prevailing culture in their organizations. Therefore, the leadership must constantly analyse the relevance of corporate values seeking their evolution, thus allowing their adaptation and the development of behaviours that support the enlargement of the desired organizational culture.

As for the organizational culture, Schein (2010) states that it is not possible to ensure whether a culture is 'good' or 'bad', as this depends on the organization's relationship with the external environment. The most curious feature of culture as a concept is that it tells about facts that are below the surface and are invisible, sometimes unconscious. "In another sense, culture is for a group what personality or character is for an individual" (SCHEIN, 2010). That is, it is possible to observe the consequences and behaviours, which are its effect, however, most of the time we do not realise the dynamics that cause them. 
Prajogo and Mcdermott (2005) point out that there is no consensus in the literature on the nature of the relationship between the concepts of Quality Management and Organizational Culture, since a group of authors argue that quality management practices bring cultural changes and another group understands that it is the organizational culture that affects the implementation of quality management practices and their results. There is, hence, a causal debate in this direction.

Aiming to fill this gap, this research's objective was to better understand the relationship between organizational culture and quality management systems through systematic literature review, seeking to identify which aspects and models of organizational culture are most addressed in research on the theme, as well as how many studies related these themes in the utilities sector and which aspects of quality management were most related to organizational culture.

This paper will follow this structure: theoretical review covering the concepts of (ii) Organizational Culture and (iii) Quality Management System; (iv) Methodological procedures; (v) Results; (vi) Discussions; and (vii) Conclusions.

\section{ORGANIZATIONAL CULTURE}

Organizational culture is a topic widely explored in the literature and has been addressed by several authors since the 20th century. In general, culture is seen as "the totality of socially transmitted behaviours, patterns, arts, beliefs, institutions and other products of human work and characteristics of thought of a community or population" (CORBETT; RASTRICK, 2000).

Schein (2010) defines culture as a standardized sharing of what the author calls basic assumptions absorbed by the group during moments of problem solving, both internal and external. Hofstede (2003), on the other hand, treats culture as the "mental coding" of each 
element of the social web, organization or group experiences, according to which everyone can act coherently. Culture, in this sense, can also be understood as a set of attributes or typical behaviours (manifest culture) with four different levels: symbols, heroes, values and rituals.

There are different levels of analysis of cultures, which can be evaluated at the national, regional, and professional sphere, related to gender and colour, among others. The culture of an organization, for instance, can be observed by what is valued, by the predominant leadership styles, by the language and symbols, procedures and routines and the definitions of success. In the business environment, functional departments, hierarchical levels or teams have their own cultures. Thus, to a certain extent, the coordination and process integration problems may reflect cultural conflicts between these different groups. Therefore, it is not surprising to see how cultural differences are capable of disrupting the organization, making effectiveness difficult to achieve (CAMERON; QUINN, 2011).

Cameron and Quinn (2011), based on a series of empirical studies, developed a diagnostic model of organizational culture that has been used a lot recently by several researchers (GAMBI et al., 2015; GIMENEZ-ESPIN; JIMÉNEZ-JIMÉNEZ; MARTÍNEZCOSTA，2013; PANUWATWANICH; NGUYEN，2017; WILLAR; TRIGUNARSYAH; COFFEY, 2016; ZGODAVOVA; HUDEC; PALFY, 2017; ZU; ROBBINS; FREDENDALL, 2010). The purpose of the model, known as the Competing Values Framework (CVF), is to diagnose and facilitate change in organizational culture (CAMERON; QUINN, 2011).

According to these authors, CVF is also useful in the organization in several aspects of total quality management (TQM), highlighting its comprehensive nature. For them, the main reason for the failures in implementing TQM is its partial or full implementation without considering the change in culture. 


\section{QUALITY MANAGEMENT SYSTEMS}

The history of the development of corporate Quality Management is extensive, so it is possible to classify it in Eras. The first of these is known as the "Inspection Era" and had a more technical view of quality and failure to obtain adequate characteristics, as a problem to be solved, with the inspection department being the main responsible for quality in companies. The second Era, called "Statistical Process Control", was primarily concerned with control and had emphasis on product uniformity and less inspection. In the third Era, which became known as "Quality Assurance", the role of quality professionals was to plan, measure quality and develop programs. Their main interest was to adopt procedural requirements. Finally, the "Total Quality Management" Era was primarily concerned with the strategic impact of quality, with emphasis on meeting the needs of the market and the customer, while everyone in the company being responsible for quality and leadership playing a fundamental role (CARVALHO, 2005).

According to Sun (2000), a management system is a tool that influences in a systematic, integrated and consistent way the perspectives that involve everyone and everything in an organization, offering a generic concept to improve performance. Frosini and Carvalho (1995), conceptualize the management system as the set of personnel, resources and procedures within any level of complexity, whose associated components interact in an organized manner to accomplish specific tasks and achieve or maintain a given result. A wellstructured and implemented management system should include management practices, instructions and manuals.

The concept of Total Quality (TQM) is quite broad and creates an idea of the organization's connection with the market, when the concept of 'quality' is understood as the 'suitability of a product for use'. Total Quality means a set of characteristics that fully serve the customer. The immediate consequence of this idea is that if the customers are fully served, 
they will not look for another organization. From this framework emerges the first indicator to measure the total quality, the degree of customer loyalty. However, customer loyalty is a gradual process that is made possible by the organization's intense contact with the markets. It is concluded, therefore, that the total meeting to the clients' requirements is an external dimension of the total quality and that it needs an internal complement to materialize. This internal element is, of course, the commitment of all those involved in the company's production process, who are directly or indirectly linked to the customer (PALADINI, 2009).

Vitoreli and Carpinetti (2013) emphasize that, in order to understand the concept of management system, it is important to understand the concept of system first. According to Churchman (1972), a system is a set of coordinated parts to accomplish a set of purposes. For Ribeiro Neto; Tavares and Hoffmann, (2008), systems are seen as a set of coordinated parts that interact in order to achieve certain goals.

A system depends on its entire structure; it does not depend only on the functioning of its parts. Thus, in order to understand a system, we need to study both its elements in isolation and its functioning as a whole. Systems can be viewed from their circles of influence or feedback. In this sense, one starts from one of its elements and establishes its relations with the others until the cycle is complete. Cycles can be positive or negative, when positive, they provide growth (virtuous or vicious), amplifying changes; when negative, they act to avoid changes and maintain stability (RIBEIRO NETO; TAVARES; HOFFMANN, 2008).

Based on this understanding, one can seek to understand the quality management systems, which are widely disseminated by the implementation of the ISO 9000 standard and its derivations. The ISO 9000: 2015 standard conceptualizes quality management systems as "activities by which the organization identifies its objectives and determines its processes and resources necessary to achieve the desired results" (ABNT, 2015). Thus, like any system, it has objectives and elements that compose it. In general, the main components of the ISO management systems are structured based on the PDCA approach (PLAN, DO, CHECK AND 
ACT), that is, to plan, do, check and act. However, the real foundations of this system are the set of values that guide it (RIBEIRO NETO; TAVARES; HOFFMANN, 2008).

According to the ISO 9000 standard (ABNT, 2015), the first of these principles is called "customer focus", that is, the priority of a quality management system is to meet the needs of customers in order to exceed their expectations. Each and every organization only survives due to its customers, and it is essential to meet their demands (RIBEIRO NETO; TAVARES; HOFFMANN, 2008). The main benefits of adopting this principle, as well as how to measure its reach, can be, for example, the increase in customer satisfaction and loyalty to the organization's products and services.

The benefits of quality management systems (QMS) have been explored in several academic researches, especially those derived from certifiable standards such as ISO 9001. In general, empirical studies bring mixed results on the expected benefits of quality management. Although some research shows that the implementation of QMS offers internal (related to the organization) and external (related to the market) benefits, other studies are able to partially confirm these findings (MARIMON; MELÃO; BASTIDA, 2019).

According to Marimon; Melão and Bastida (2019), a growing number of empirical studies highlights that quality management practices depend on the organizational context and, consequently, there is a tendency to analyse the role of contextual factors in the results of the QMS. In the literature on ISO 9001, empirical studies have supported that the impacts of QMS differ according to certification motivations, implementation processes, activity sectors and the organization size.

For Tarí et al (2020), most research that deals with quality standards (for example, ISO 9001) assumes a homogeneous adoption of the standard, that is, they believe that all organizations adopt quality standards in the same way. However, even though these studies are fundamental to explain the effects of quality standards, they fail to clarify the process of heterogeneous adoption of standards (internalization), as they only evaluate adoption in 
binary terms (certified or non-certified company). When organizations effectively internalize standards, it is easier for them to achieve effective benefits. Results show that greater internalization brings better operational results and other advantages, such as the formation of a culture of quality, the improvement of customer satisfaction and benefits for employees and society (TARÍ et al., 2020).

Furthermore, according to the authors, in order to obtain the effective benefits of implementing quality standards, some aspects are fundamental, such as leadership commitment, employee training and the adoption of a culture of continuous improvement. In addition, companies that are certified due to internal reasons (authentic desire to improve) face fewer difficulties than those that focus on external reasons (demands from suppliers and the market) (TARÍ et al., 2020).

Finally, for Wawak; Rogala and Dahlgaard-Park (2020) it is possible to affirm that the theme of Quality Management is mature and well established, which can be evidenced by the number of scientific journals dedicated to the subject and the various works published every year. According to the authors, research shows that the field is still evolving, with researchers suggesting new applications; changes in known methods; development of new tools, models and concepts. Regarding the trends in the field, we can mention the growth in research that links quality management to Lean and Six Sigma methodologies; supply chain management, innovation and creativity, sustainability and customer loyalty. On the other hand, the downward themes, which have been little discussed in the area, are: management excellence model, quality costs, quality in electronic services, knowledge management and process capacity (WAWAK; ROGALA; DAHLGAARD-PARK, 2020).

\section{METHODOLOGICAL PROCEDURES}

According to Boiral (2012), the literature review provides various interested audiences 
with access to certain subjects and numerous concepts without having to read the many related publications, providing a comprehensive picture of growth and critical literature on the topic. Although these analyses are not intended to develop or test new theories, the review clearly contributes to pointing out trends, limitations and possible future research (BOIRAL, 2012).

This literature review follows the process proposed by Kitchenham et al. (2009) and consists of three stages: planning, conducting the research and presenting its results. The planning stage aimed to identify the need to carry out the research considering the context studied, as well as to establish the questions that guided the study. The questions used in the survey can be seen in Table 1 .

In line with the review goals, criteria were selected to be observed when reading the selected papers. The papers were evaluated according to the following criteria: assessed conceptual model of organizational culture, researched business sector, quality aspects addressed, surveyed audience, research type and methodology, collection instrument tool used to assess organizational culture, country of origin of study and publication year.

Regarding the conceptual models of organizational culture and tools used for the evaluation, the classification was based on the theories by classic authors recognized in relation to the theme (SCHEIN, 2010; HOFSTEDE, 2003) and others more contemporary (CAMERON; QUINN, 2011). The conceptual models different from these main ones were classified as 'other'.

In order to classify the business sectors surveyed in the texts, the GICS - Global Industry Classification Standard, an industry taxonomy developed in 1999 for use by the global financial community, was used. The GICS structure consists of 11 sectors, 24 industrial groups, 69 industries and 158 sub-industries. The GICS is used as the basis for the financial market indices S\&P 500 and MSCI, in which each company is classified by its main commercial activity. 
The classification of the quality aspects addressed in the analysed research started from a binary point of view, which divides the quality management practices into two dimensions, hard and soft. According to Abdullah and Tarí (2012), there is some alignment in the literature on the hard and soft elements of quality management practices. The soft dimension (management system) is related to topics such as leadership, planning, human resources, among others, while the hard dimension (technical system) is linked to production control, techniques and work processes, and includes process design, just-in-time philosophy, ISO 9000 standard and quality control principles and tools (ABDULLAH; TARÍ, 2012).

Table 1 - Research Questions for Systematic Literature Review

\begin{tabular}{c|l|l} 
ID & \multicolumn{1}{|c|}{ RESEARCH QUESTION } & \multicolumn{1}{|c}{ OBJECTIVE } \\
\hline Q1 & $\begin{array}{l}\text { Which aspects and / or models of } \\
\text { organizational culture are the most } \\
\text { addressed in research on the topic? }\end{array}$ & $\begin{array}{l}\text { The organizational culture varies from organization to } \\
\text { organization and across sectors. There are different } \\
\text { ways an models to understand a company's } \\
\text { organizational culture. The purpose of this question is } \\
\text { to identify the main theoretical models of } \\
\text { organizational culture used in research. }\end{array}$ \\
\hline Q2 & $\begin{array}{l}\text { How many and which studies relate the } \\
\text { theme of organizational culture and } \\
\text { quality management systems in the } \\
\text { utilities sector? }\end{array}$ & $\begin{array}{l}\text { As this review originated from an R\&D (Research and } \\
\text { Development) project, it was important to understand } \\
\text { how the concepts evaluated in this review are } \\
\text { addressed in research in companies of the utilities } \\
\text { sector. It is also important to know whether there is } \\
\text { research that addresses and relates QMS and } \\
\text { organizational culture in this sector. }\end{array}$ \\
\hline Q3 & $\begin{array}{l}\text { Which aspects of management systems } \\
\text { are influenced by organizational } \\
\text { culture? }\end{array}$ & $\begin{array}{l}\text { The concept of quality management is very broad, so it } \\
\text { is necessary to understand how this subject is related to } \\
\text { the concept of organizational culture in the various } \\
\text { surveys that address these themes. }\end{array}$
\end{tabular}

Source: prepared by the authors. 


\section{RESULTS}

The search and collection of studies in the databases were carried out in May 2020, through the generic sequence of searches with the combination of keywords. The parameters used in the research can be seen in Table 2 .

Table 2 - Research Parameters

\begin{tabular}{l|l}
$\begin{array}{l}\text { Accomplished } \\
\text { in }\end{array}$ & $05 / 15 / 2020$ \\
\hline Period & Unrestricted \\
\hline Data Base & $\begin{array}{l}\text { Materials Science \& Engineering Database, Emerald Insight, OneFile (GALE), Taylor \& } \\
\text { Francis Online - Journals, ScienceDirect Journals (Elsevier), Elsevier (CrossRef), Directory } \\
\text { of Open Access Journals (DOAJ), MEDLINE/PubMed (NLM), Library \& Information } \\
\text { Science Collection e Springer (CrossRef) }\end{array}$ \\
\hline $\begin{array}{l}\text { Research } \\
\text { Fields }\end{array}$ & Title, key-words and abstract. \\
\hline $\begin{array}{l}\text { Research } \\
\text { Terms }\end{array}$ & "organization culture" or "quality management system" \\
\hline $\begin{array}{l}\text { Inclusion } \\
\text { Criteria }\end{array}$ & $\begin{array}{l}\text { Only peer-reviewed scientific papers were considered; the title or abstract should contain the } \\
\text { terms searched; only in Portuguese, Spanish or English. }\end{array}$ \\
\hline $\begin{array}{l}\text { Exclusion } \\
\text { Criteria }\end{array}$ & $\begin{array}{l}\text { Only in Portuguese, Spanish or English; Books, theses, editorials, prefaces, papers' abstracts, } \\
\text { interviews, news, comments, correspondence, debates, reader letters, summaries of tutorials, } \\
\text { workshops, panels, dissertations and poster session; Corrupted, duplicated and or redundant } \\
\text { documents. }\end{array}$ \\
\hline $\begin{array}{l}\text { Type of } \\
\text { Publication }\end{array}$ & Papers \\
\hline $\begin{array}{l}\text { Level of } \\
\text { Publication }\end{array}$ & Unrestricted \\
\hline Languages & Portuguese, English and Spanish
\end{tabular}

Source: Research data.

The abstracts of all 486 papers found were analysed in order to assess whether the themes were treated in an integrated manner in the research and whether they addressed the relationships between them. After reading all abstracts, 18 papers were selected. However, in 
order to ensure that important theoretical contributions were not left out of the sample and for the review to fulfil its role, the snowballing technique was used in the references of the 18 pre-selected papers.

The Snowballing (SB) method consists of searching for papers and articles from reference lists from other studies to identify additional relevant documents and it is recommended that it be used as a complement to the database search (Database - DB) (BADAMPUDI; WOHLIN; PETERSEN, 2015).

The use of the SB method added 4 more articles to the 18 pre-selected, totalling 22 reviewed papers. The inclusion of these 4 articles was mainly due to the fact that they were not filtered in the search for the selected databases and also because they were included in at least 3 of the reference lists of the 18 analysed papers.

Subsequently, the 22 papers were fully read, analysed and classified according to the categories defined in this literature review. After the complete reading of them, it was found that 6 of them were not empirical works, only essays, thus, 16 articles remained that effectively met the pre-established criteria. Table 1 summarizes this information.

Table 1 - Summary of Assessed Papers

\begin{tabular}{c|l|c|c|c|c} 
ID & \multicolumn{1}{|c|}{ PAPER } & AUTHOR & CRITERION & COUNTRY & YEAR \\
\hline 1 & $\begin{array}{l}\text { Organizational Culture, Rewards and Quality in } \\
\text { Higher Education }\end{array}$ & $\begin{array}{c}\text { Hart and } \\
\text { Shoolbred }\end{array}$ & Ruled out & Australia & 1993 \\
\hline 2 & Total quality - Systems survive, cultures change & Shadur & Ruled out & Australia & 1995 \\
\hline 3 & $\begin{array}{l}\text { Are the cultures required to attain ISO 9000 } \\
\text { and total quality management mutually } \\
\text { exclusive? }\end{array}$ & Hind & Ruled out & UK & 1996 \\
\hline 4 & $\begin{array}{l}\text { Factors affecting a senior management culture } \\
\text { change for total quality metamorphosis }\end{array}$ & $\begin{array}{c}\text { Angeli, Jones } \\
\text { and Sabir }\end{array}$ & Listed & Cyprus and UK & 1998 \\
\hline 5 & $\begin{array}{l}\text { Quality performance and organizational culture } \\
\text { Corbett and } \\
\text { Rastrick }\end{array}$ & Listed & New Zealand & 2000
\end{tabular}




\begin{tabular}{|c|c|c|c|c|c|}
\hline 6 & $\begin{array}{l}\text { Cultural influences on total quality management } \\
\text { adoption in Chinese enterprises: An empirical } \\
\text { study }\end{array}$ & Pun & Listed SB & Hong Kong & 2001 \\
\hline 7 & $\begin{array}{l}\text { Organisational Culture and Quality } \\
\text { Improvement }\end{array}$ & $\begin{array}{l}\text { Maull, Brown } \\
\text { and Cliffe }\end{array}$ & Listed SB & UK & 2001 \\
\hline 8 & $\begin{array}{l}\text { Total quality management and corporate } \\
\text { culture: } \\
\text { organisational excellence }\end{array}$ & $\begin{array}{l}\text { Irani, Beskese } \\
\text { and Love }\end{array}$ & Listed SB & UK & 2004 \\
\hline 9 & $\begin{array}{l}\text { The impact of organizational culture on the } \\
\text { successful implementation of total quality } \\
\text { management }\end{array}$ & $\begin{array}{c}\text { Mohammad } \\
\text { Mosadegh Rad }\end{array}$ & Listed & Iran & 2006 \\
\hline 10 & $\begin{array}{l}\text { Effects of Quality Culture and Corporate } \\
\text { Ethical Values on Employee Work Attitudes and } \\
\text { Job Performance in Turkey: An Integrative } \\
\text { Approach } \\
\end{array}$ & $\begin{array}{l}\text { Elçi, Kitapçi } \\
\text { and Ertürk }\end{array}$ & Listed & Turkey & 2007 \\
\hline 11 & Understanding quality culture & Ehlers & Ruled out & Germany & 2009 \\
\hline 12 & $\begin{array}{l}\text { Quality management and safety culture in } \\
\text { medicine - Do standard quality reports provide } \\
\text { insights into the human factor of patient safety? }\end{array}$ & $\begin{array}{l}\text { Wischet and } \\
\text { Schusterschitz }\end{array}$ & Listed & Austria & 2009 \\
\hline 13 & $\begin{array}{|lr|}\text { Mapping the Critical Links Between } \\
\text { Organizational Culture } & \text { and } \\
\text { TQM/Six Sigma Practices } & \\
\end{array}$ & $\begin{array}{l}\mathrm{Zu}, \text { Robbins E } \\
\text { Fredendall }\end{array}$ & Listed SB & USA & 2010 \\
\hline 14 & $\begin{array}{l}\text { Impacts of company size and culture on quality } \\
\text { management practices in manufacturing } \\
\text { organisations }\end{array}$ & $\begin{array}{l}\text { Fai Pun and } \\
\text { Jaggernath- } \\
\text { Furlonge }\end{array}$ & Listed & $\begin{array}{l}\text { Trinidad \& } \\
\text { Tobago }\end{array}$ & 2012 \\
\hline 15 & $\begin{array}{l}\text { Total quality management practices, quality } \\
\text { culture and contractors' competitiveness }\end{array}$ & $\begin{array}{l}\text { Alotaibi and } \\
\text { Islam }\end{array}$ & Ruled out & Saudi Arabia & 2013 \\
\hline 16 & $\begin{array}{l}\text { Organizational culture for total quality } \\
\text { management }\end{array}$ & $\begin{array}{l}\text { Gimenez- } \\
\text { Espin, } \\
\text { Jiménez- } \\
\text { Jiménez and } \\
\text { Martínez- } \\
\text { Costa }\end{array}$ & Listed & Spain & 2013 \\
\hline 17 & $\begin{array}{l}\text { Assessment and cultivation of total quality } \\
\text { management organisational culture }- \text { an } \\
\text { empirical investigation }\end{array}$ & Fu et al. & Listed & Taiwan & 2014 \\
\hline 18 & $\begin{array}{l}\text { The relationship between organizational culture } \\
\text { and quality techniques, and its impact on } \\
\text { operational performance }\end{array}$ & Gambi et al. & Listed & $\begin{array}{l}\text { Brazil/Denmar } \\
\text { k }\end{array}$ & 2015 \\
\hline
\end{tabular}




\begin{tabular}{|c|c|c|c|c|c|}
\hline 19 & $\begin{array}{l}\text { Organisational culture and quality management } \\
\text { system implementation in Indonesian } \\
\text { construction companies }\end{array}$ & $\begin{array}{l}\text { Willar, } \\
\text { Trigunarsyah } \\
\text { and Coffey }\end{array}$ & Listed & Indonesia & 2016 \\
\hline 20 & Building quality culture in higher education & $\begin{array}{l}\text { Lycke and } \\
\text { Tano }\end{array}$ & Ruled out & Sweden & 2017 \\
\hline 21 & $\begin{array}{l}\text { Culture of quality: insight into foreign } \\
\text { organisations in Slovakia }\end{array}$ & $\begin{array}{l}\text { Zgodavova, } \\
\text { Hudec and } \\
\text { Palfy }\end{array}$ & Listed & Slovakia & 2017 \\
\hline 22 & $\begin{array}{l}\text { Influence of Organisational Culture on Total } \\
\text { Quality Management Implementation and Firm } \\
\text { Performance: Evidence from the Vietnamese } \\
\text { Construction Industry }\end{array}$ & $\begin{array}{l}\text { Panuwatwanic } \\
\text { h and Nguyen }\end{array}$ & Listed & Vietnam & 2017 \\
\hline
\end{tabular}

Source: Research data.

\section{DISCUSSION}

The results of the systematic literature review will be discussed according to the research questions established in the methodology section.

6.1. Which aspects and / or models of organizational culture are the most addressed in research on the topic?

Regarding the theoretical models of organizational culture used in research, as well as the instruments used to assess culture, it is clear that most of the papers analysed used the model / instrument developed by Cameron and Quinn (2011) in their research, the Organizational Culture Assessment Instrument (OCAI), which is based on the Competing Values Framework (CVF), Structure of Concurrent Values, a theoretical model that has become a world reference for evaluating organizational culture. The CVF was developed for diagnosis and culture change, has high empirical validity, and is the result of the diverse cultural dimensions proposed by renowned authors in this area (CAMERON; QUINN, 2011). 
The choice for this model by the authors of the analysed papers was made for several reasons; the main ones are: being a model that defines a widely accepted typology of organizational cultures and having been used in many empirical studies (GIMENEZ-ESPIN; JIMÉNEZ-JIMÉNEZ ; MARTÍNEZ-COSTA, 2013); be a well-established and theoretically sound instrument, in addition to being widely used in quality management studies (GAMBI et al., 2015); due to its suitability to identify the organizational culture profiles of the industrial sector, offering an understanding of how complex phenomena act in this type of company (WILLAR; TRIGUNARSYAH; COFFEY, 2016); to be one of the most adopted approaches to evaluate organizational culture in the last decades and that counted on specialists in its construction (PANUWATWANICH; NGUYEN, 2017; ZGODAVOVA; HUDEC; PALFY, 2017); and for having demonstrated satisfactory psychometric properties (ZU; ROBBINS; FREDENDALL, 2010).

Gimenez-Espin, Jiménez-Jiménez and Martínez-Costa (2013), sought to find empirical evidence about the organizational culture that best fit a total quality management system (TQM) and used the CVF to identify the type of culture prevalent in research organizations. Gambi et al. (2015) used the CVF to investigate whether the pluralist view of organizational culture also applied to quality techniques and to what extent the set of techniques used in an organization affected the performance effects of its organizational culture.

The research of Zgodavova, Hudec and Palfy (2017), which sought to compare the different quality cultures in organizations active in the automotive industry in Slovakia, also used the CVF structure. The research by Willar, Trigunarsyah and Coffey (2016) shows the types of organizational culture and their influences in the implementation of the principles and elements of ISO 9000, relating these aspects to the quality performance of companies; for this, they used the CVF as a culture survey tool.

Another research that used the framework developed by Cameron and Quinn (2011) was carried out by Panuwatwanich and Nguyen (2017), who examined the relationship 
between organizational culture and TQM and the influence of implementing TQM on improving organizational performance within the context of the Vietnamese construction industry. Zu, Robbins and Fredendall (2010) used the CVF as an additional tool to investigate the relationship between the implementation of TQM / Six Sigma and the organizational culture in American companies. The survey instrument was administered to 878 representatives of companies, obtaining a response rate of $26 \%$ (ZU; ROBBINS; FREDENDALL, 2010).

Few studies have used other models and tools to assess organizational culture in their work. Angeli; Jones and Sabir (1998) did not specify the tool used. Corbett and Rastrick (2000) used the Organizational Culture Inventory or Inventory of Organizational Culture (OCI) by Cooke and Rousseau (1988), a system of self-assessment and diagnosis focused on individual change and organizational development. Elçi; Kitapçi and Ertürk (2007) evaluated the culture of quality using an 11-item questionnaire adapted from Ahire et al. (1996).

Pun (2001) conducted research with leaders of Chinese companies and to assess the organizational culture developed 20 questions that addressed their perception of Chinese cultural values. Irani, Beskese and Love (2004) carried out a case study in a prominent company in the United Kingdom and, in order to identify the cultural factors aligned with the high quality observed in this organization, they used in-depth interviews.

Maull, Brown and Cliffe (2001) evaluated how the organizational culture influenced the implementation of quality improvement in branches of a financial institution and, for that, they developed their own questionnaire that evaluated the organizational culture, as well as aspects related to the organizational environment. 


\section{Image 1 - Verified Organizational Culture Models}

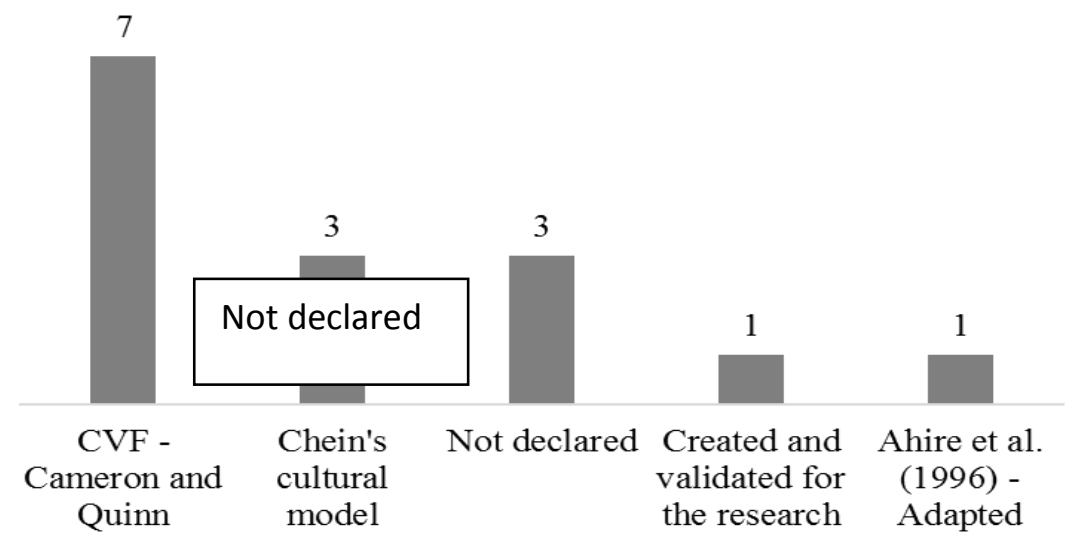

Source: Research data.

6.2. How many and which studies relate the theme of organizational culture and quality management systems in the utilities sector?

The authors of the analysed papers conducted their research in several business sectors.

Some of them collected data from different sectors in the same survey, however, what can be seen is that most concentrated in the industrial sector, as can be seen in Image 2, representing $38 \%$ of the studies found.

The predominance of the industrial sector over other sectors can be explained, since quality management, one of the main concepts of this review, started in the manufacturing sector. This is due, in part, to the fact that the movement of total quality was centred on performance measurement, this aspect being more easily assessed with "physical" and tangible products. For instance, Shewhart (1931), one of the well-known quality theorists, introduced his statistical control charts as a method to improve the quality of mass product 
manufacturing, these techniques being expanded during the 1930s and applied to the war industry during World War II (MOHANTY; BEHERA, 1996; MILAKOVICH, 1990).

Image 2 - Business Sectors Found in the Literature Review

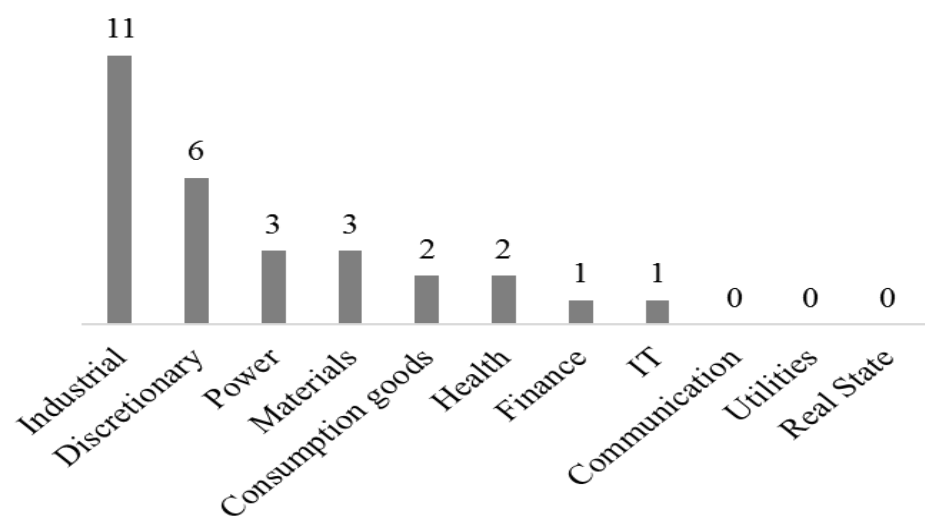

Source: Research data.

For instance, Corbett and Rastrick (2000) conducted their research in manufacturing industries in New Zealand and Australia. Elçi, Kitapçi and Ertürk (2007), in turn, collected the perceptions of more than 200 employees from industrial organizations in Turkey.

Gimenez-Espin, Jiménez-Jiménez and Martínez-Costa (2013) targeted Spanish companies located in the southeast of the country, with 50 or more workers. The initial study population consisted of 1600 companies. The number of valid questionnaires returned was 451 (25.2\%), of which 251 corresponded to industrial companies (55.6\%) and 200 to service companies $(44.3 \%)$.

Fu et al. (2014) used seven Taiwanese companies in their sample that achieved a high level of excellence, among them, several from the industrial sector. These companies had been practicing Total Quality for five years or more and were nationally recognized for their quality. 
Gambi et al. (2015) were based on questionnaire data sent by email to a random sample of 1,761 Brazilian and Danish manufacturing companies, obtaining a response rate of 14.2\% (250 companies). Willar, Trigunarsyah and Coffey (2016) researched certified grade 7 (G-7) construction companies, the highest qualification level for Indonesian contractors.

Panuwatwanich and Nguyen (2017) used samples from 44 organizations. In total, there were 104 valid responses. Regarding the companies size, $38.5 \%$ of respondents were from companies with more than 50 employees, $25 \%$ from medium-sized companies and $36.5 \%$ from large companies (over 100 employees).

Fai Pun and Jaggernath-Furlonge (2012) used as sample manufacturing companies active in Trinidad and Tobago. These companies were categorized in the sectors of power, construction, food and beverage, clothing, chemicals, plastics and printing and packaging. Mohammad Mosadegh Rad (2006) applied questionnaires to hospital managers and employees in Iran. Zgodavova, Hudec and Palfy (2017) conducted their research in the automotive industry in Slovakia. Angeli, Jones and Sabir (1998) researched CEOs from 15 different countries; however they did not specify the business sectors surveyed in their paper.

Pun (2001) sent their questionnaire to 422 Hong Kong organizations and 84 other Chinese companies. The first group was selected through the Hong Kong Productivity Council (1998) or the Hong Kong Industry Directory (1998) (HKPC). The sample was composed in large part by joint ventures, state, private and foreign. Maull, Brown and Cliffe (2001) applied their research at different managerial levels in 5 units of a financial institution.

$\mathrm{Zu}$, Robbins and Fredendall (2010) obtained samples from the transportation equipment (32\%), electrical equipment (16\%) and metal products $(20 \%)$ industries.

\subsection{What aspects of quality management systems are influenced by organizational culture?}

The classification of the quality aspects addressed in the analysed studies started from 
a binary point of view, which divides the quality management practices into two dimensions, hard and soft. The soft dimension is related to topics such as leadership, planning, human resources, among others, while the hard dimension is linked to production control, techniques and work processes, and includes process design, just-in-time philosophy, ISO standard and quality control principles and tools. (ABDULLAH; TARÍ, 2012).

Image 3 shows the percentage of research that addressed these two dimensions. It appears that both dimensions were treated simultaneously in most studies (56\%), with $31 \%$ of them addressing only the soft dimension and $13 \%$ dealing only with the hard dimension.

Image 3 - Quality Aspects Assessed in the Researched Works

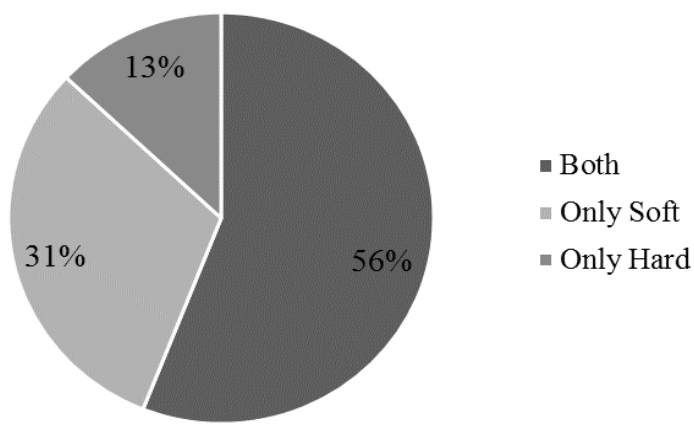

Source: Research data.

The main quality aspects related to the organizational culture found in the review were: quality principles (as described in ISO 9000), barriers to the implementation of quality management in organizations, quality management tools and techniques used and performance indicators.

Mohammad Mosadegh Rad (2006) developed questionnaires to measure the success of 
TQM and its barriers to implementation in hospitals. The questions were defined through literature review and Delphi technique. The author assessed the most common principles of TQM and five domains of TQM implementation barriers (resources, performance evaluation, strategy, structural and procedural barriers).

The research by Fai Pun and Jaggernath-Furlonge (2012) aimed to investigate the impacts of company size and culture on Quality Management Practices or QMP. With regard to the evaluated quality aspects management, the authors divided into two factors extracted from 16 items of QMP benefits and four factors extracted from 15 items of QMP barriers. Regarding the benefits of the QMP, the ease of communication between leadership and employees, the decentralization of functions, the reduction of absenteeism and the involvement of the team were analysed. In relation to barriers, the bureaucratic culture, the centralization of roles and the complex hierarchical structures were analysed.

In the research by Willar, Trigunarsyah and Coffey (2016), the questions related to quality management were about the implementation of the QMS and were based on the literature, divided into problems in the implementation of the quality system, the implementation of the principles of ISO 9000 and the business performance of companies when implementing their QMS.

Angeli, Jones and Sabir (1998) used the Delphi method and the QFD tool (Quality Function Deployment) to identify with specialists what are the appropriate behaviours to be adopted by leaders in order to achieve cultural change aiming at a transformation in organizations' quality management practices.

Corbett and Rastrick (2000) related the organizational culture to some quality indicators, such as, percentage of defective materials received by suppliers, percentages of defective products, cost of quality in relation to total sales, percentage of deliveries to the customer made within deadline, etc. These aspects, according to Abdullah and Tarí (2012), can be considered as hard. 
Elçi, Kitapçi and Ertürk (2007) related the quality culture with commitment and satisfaction of employees, job performance and intention to turnover, denoting an orientation towards soft aspects of quality management. Gimenez-Espin, Jiménez-Jiménez and MartínezCosta (2013) evaluated aspects such as leadership, information, process control, continuous improvement, training in quality tools and teamwork, relationship with suppliers and customer orientation.

Fu et al. (2014) divided their research instrument into three parts: TQM approaches and tools; the subjective perception of performance in relation to the six core values of TQM and underlying assumptions; and secondary data. The first part consisted of 30 TQM approaches and tools that were used in each of the companies, for example, Six Sigma, Quality Control Circles (CCQ), Process Reengineering, Benchmarking, Quality Tools, QFD, Statistical Process Control or Statistical Process Control (SPC), Just in Time, among others. The second part consisted of evaluating performance in relation to the six main values of TQM and underlying assumptions perceived by employees. This part consisted of a questionnaire with 33 items derived from the literature review, such as leadership, customer focus, employee focus, fact-based decision making, continuous improvement and commitment.

Gambi et al. (2015), in one of their developed models, analysed the relationship between the types of organizational culture and what the authors called groups of quality techniques, such as strategic goals, continuous improvement, measurement, monitoring and control and prevention of failures. Zgodavova; Hudec and Palfy (2017), in turn, dealt with aspects more related to the soft dimension, such as strategy, quality vision and values, leadership and involvement with the client. Panuwatwanich and Nguyen (2017) analysed the relationship between organizational culture and the following quality practices: leadership, training, employee relations, data and reporting quality, supply chain management, process and project management. 
$\mathrm{Zu}$, Robbins and Fredendall (2010) analysed the support aspects of leadership, customer and supplier relationships; people management; quality of information; product development; management of processes and structure, procedures and metrics Six Sigma (ZU; ROBBINS; FREDENDALL, 2010).

Pun (2001) related the organizational culture to the following aspects of TQM: relationship with customers and suppliers; self-inspection; simplification of work; monitoring the cost of quality; quality work team activities and just-in-time practices.

Finally, Maull, Brown and Cliffe (2001) developed the questionnaire Personal Customer Orientation, Organizational and Cultural Issues (PCOC), used to measure culture and the organizational environment. The questionnaire addressed the following aspects related to quality: innovation and problem solving; customer orientation; hierarchy; strategy planning and processes.

The predominance of the "soft" aspects of quality verified in this review can be explained, since they are, in general, related to managerial aspects such as leadership, people management, relationship with customers and suppliers and quality of planning and these aspects have greater alignment with the organizational culture theme. In addition, according to Abdullah and Tarí (2012), some soft quality management factors can have positive effects on performance. The authors also cite other research that demonstrated that the results obtained through the hard factors depend significantly on the soft aspects (ABDULLAH; TARÍ, 2012).

Regarding the methodologies used in the analysed papers, it appears that most studies used quantitative methodology, being, obviously, the predominant data collection instrument the questionnaire, representing $81 \%$ of the analysed research (Image 4). The other works applied interviews. 
Image 4 - Main Identified Data Collection Instruments

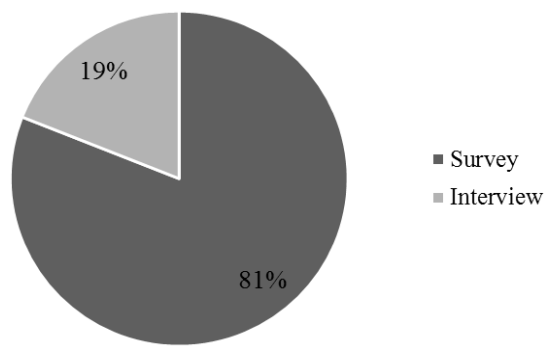

Source: Research data.

According to Karami, Rowley and Analoui (2006), the choice for quantitative or qualitative methods has always been controversial. The predominance of quantitative methodological options in management research does not necessarily imply that this method is suitable for all issues raised. For the authors, the context of the research is that it must determine the choice of the method (KARAMI; ROWLEY; ANALOUI, 2006).

Karami, Rowley and Analoui (2006) developed research seeking to answer about the methodological nature used in research in administration / management through the analysis of 120 articles published between 1991 and 2000. The conclusions of the work showed a predominance of questionnaires as data collection tools, suggesting a tendency towards positivism and quantification in the construction of knowledge in this area. For the authors, this finding serves to indicate the types of research agendas and the questions asked by researchers in administration / management, suggesting a search for laws and quantitatively rigorous models.

Regarding the profile of the surveyed audience, there is a predominance of managerial levels in relation to the other hierarchical levels, as shown in Image 5.

The fact that there is a predominance of managerial levels in the studies analysed may 
be related to the fact that organizational culture and leadership are seen as two faces of the same structure, since leadership affects culture as much as culture influences leadership . Top leadership gives rise to organizational culture based on their stories and personalities, which may justify the fact that research on the topic often deals with the impact of founders or leaders on a company's culture (CHONG et al., 2018 ). Cameron and Quinn (2018), in the development process of OCAI, realised that there is a great congruence between the type of culture prevalent in an organization and the competencies presented by the leadership. "When an individual's leadership forces are congruent with the dominant organizational culture, these leaders tend to be more successful, as are the units they manage" (CAMERON; QUINN, 2011, p. 54).

Image 5 - Researched Hierarchical Levels

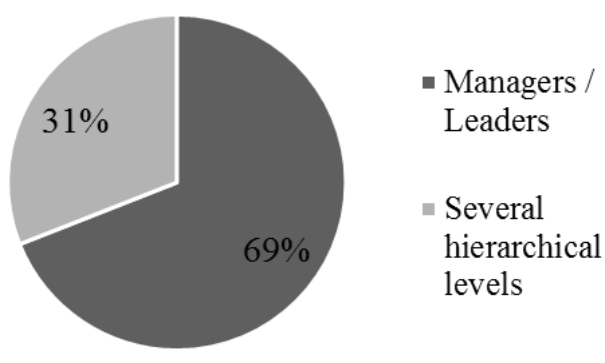

Source: Research data.

Regarding the countries in which the works were published, there is great dispersion, with little or no representation in the Americas, with the time horizon varying from 1993 to 2017. Table 2 summarizes the main results of this review. 
Table 2 - Results Summary

\begin{tabular}{l|l|l}
\multicolumn{2}{c|}{ Results } & \multicolumn{1}{c}{ Summaries } \\
\hline 1 & $\begin{array}{l}\text { Aspects and / or models of } \\
\text { organizational culture the most } \\
\text { addressed in research on the topic }\end{array}$ & $\begin{array}{l}\text { It is noticed that most of the articles analysed used in their research the } \\
\text { model / instrument developed by Cameron and Quinn (2011), the } \\
\text { Organizational Culture Assessment Instrument (OCAI), which is based } \\
\text { on the CVF. }\end{array}$ \\
\hline 3 & $\begin{array}{l}\text { Business sectors most analysed in } \\
\text { surveys }\end{array}$ & $\begin{array}{l}\text { The surveys were carried out in several business sectors, however, } \\
\text { what can be seen is that the majority concentrated on the industrial } \\
\text { sector, representing 38\% of the studies found. }\end{array}$ \\
\hline $\begin{array}{l}\text { Aspects of quality management } \\
\text { organizational culture. }\end{array}$ & $\begin{array}{l}\text { Both dimensions of quality management (Hard and Soft) were treated } \\
\text { simultaneously in most surveys (56\%), with 31\% of the surveys } \\
\text { addressing only the soft dimension and 13\% dealing only with the } \\
\text { hard dimension. }\end{array}$ \\
\hline $\begin{array}{l}\text { Countries where searches were } \\
\text { conducted }\end{array}$ & $\begin{array}{l}\text { Great dispersion is observed, with little or no representation in the } \\
\text { Americas, with the time horizon varying from 1993 to 2017. }\end{array}$ \\
\hline $\begin{array}{l}\text { Suta collection instruments used } \\
\text { Surveyed audience profile }\end{array}$ & $\begin{array}{l}\text { questionnaire being the predominant data collection instrument, } \\
\text { representing 81\% of the analysed researches. }\end{array}$ \\
\hline $\begin{array}{l}\text { There is a predominance of managerial levels in relation to other } \\
\text { hierarchical levels. }\end{array}$
\end{tabular}

\section{CONCLUSION}

This study aimed to understand the relationship between organizational culture and quality management systems through literature review, seeking to identify which aspects and models of organizational culture were most addressed in research on the topic, as well as how many studies related the theme of organizational culture and quality management systems in the utilities sector and which aspects of quality management were most influenced / addressed by the organizational culture.

The analysis shows that the conceptual model of Cameron and Quinn (2011) is the 
most used, with predominance of the use of the organizational culture assessment tool developed by those authors verified in $50 \%$ of the researched sample.

Regarding the business sectors in which the surveys were conducted, it was found that no research related to the topics surveyed in utility companies was identified, with most of the studies $(38 \%)$ carried out in companies in the industrial sector.

Regarding the aspects of quality management related to organizational culture, there is a balance in the literature between the hard and soft dimensions, that is, a large part of the research (56\%) analysed both dimensions and few of them analysed those in isolation, 13\% and $31 \%$, respectively.

Most of the surveys present the management levels of the companies (69\%) as target audience for the data source. It was also found that the majority of studies used quantitative research methodology $(73 \%)$, with the predominant data collection instrument being the questionnaire, representing $81 \%$ of the analysed research. Finally, there was little dispersion of work on the American continent, especially Latin America.

The study contributes to management professionals by sowing the concepts about organizational culture and quality management systems, comprising aspects and models addressed in the research carried out and the relationship between the constructs.

The following can be considered limitations of this study: the databases used for research, given that those considered most relevant were selected, however there is a risk of publication bias in these journals. Another important limitation was the fact that only one set of search expressions was used, incurring the risk of targeting the search. It should also be noted that the exclusion criteria have excluded papers that are relevant to the research. Considering more databases, the expansion of searches to other languages as well as the search for other sets of expressions are points to be observed when carrying out future studies that have the potential to enrich this area of knowledge. 


\section{References}

ABDUlLAH, M. M. B.; TARÍ, J. J. The Influence of Soft and Hard Quality Management Practices on Performance. Asia Pacific Management Review, v. 17, p. 177-193, 2012.

ABNT. ABNT NBR ISO 9000:2015: Sistemas de gestão da qualidade - Fundamentos e vocabulário - Associação Brasileira de Normas Técnicas. 2015. ed. Rio de Janeiro: 2015, 2015. v. 2015

ANGELI, I.; JONES, J.; SABIR, B. Factors affecting a senior management culture change for total quality metamorphosis. Managing Service Quality: An International Journal, v. 8, n. 3, p. 198-211, 1998.

BADAMPUDI, D.; WOHLIN, C.; PETERSEN, K. Experiences from using snowballing and database searches in systematic literature studies. 19th INTERNATIONAL CONFERENCE ON EVALUATION AND ASSESSMENT IN SOFTWARE ENGINEERING. Anais... In: 19TH INTERNATIONAL CONFERENCE. China: ACM Press, 2015

BOIRAL, O. ISO 9000 and Organizational Effectiveness: A Systematic Review. Quality Management Journal, v. 19, n. 3, p. 16-37, jan. 2012.

CAMERON, K. S.; QUINN, R. E. Diagnosing and Changing Organizational Culture. p. $290,2011$.

CARVALHO, M. Gestão da Qualidade: Teoria e prática. p. 1 a 23 ed. Rio de Janeiro: Elsevier, 2005.

CHONG, M. P. M. et al. Two sides of the same coin? Leadership and organizational culture. Leadership \& Organization Development Journal, v. 39, n. 8, p. 975-994, 5 nov. 2018.

CHURCHMAN, C. W. Introdução à teoria dos sistemas. Petropolis: Vozes, 1972.

CORBETT, L. M.; RASTRICK, K. N. Quality performance and organizational culture. International Journal of Quality \& Reliability Management, v. 17, n. 1, p. 14-26, 2000.

ELÇI, M.; KITAPÇI, H.; ERTÜRK, A. Effects of Quality Culture and Corporate Ethical Values on Employee Work Attitudes and Job Performance in Turkey: An Integrative Approach. Total Quality Management \& Business Excellence, v. 18, n. 3, p. 285-302, 2007. 
FAI PUN, K.; JAGGERNATH-FURLONGE, S. Impacts of company size and culture on quality management practices in manufacturing organisations. The TQM Journal, v. 24, n. 1, p. 83-101, 2012.

FROSINI, L. H.; CARVALHO, A. B. M. Segurança e Saúde na Qualidade e no MeioAmbiente. CQ Qualidade, v. São Paulo, n. 38, p. 40-45, 1995.

FU, S.-L. et al. Assessment and cultivation of total quality management organisational culture - an empirical investigation. Total Quality Management \& Business Excellence, p. 1-17, 2014.

GAMBI, L. D. N. et al. The relationship between organizational culture and quality techniques, and its impact on operational performance. International Journal of Operations \& Production Management, v. 35, n. 10, p. 1460-1484, 2015.

GIMENEZ-ESPIN, J. A.; JIMÉNEZ-JIMÉNEZ, D.; MARTÍNEZ-COSTA, M. Organizational culture for total quality management. Total Quality Management \& Business Excellence, v. 24, n. 5-6, p. 678-692, 2013.

HOFSTEDE, G. Culturas e organizações: compreender a nossa programação mental. $1^{\text {a }}$ edição ed. Portugal: Súlabo LDA, 2003.

IRANI, Z.; BESKESE, A.; LOVE, P. E. D. Total quality management and corporate culture: constructs of organisational excellence. Technovation, v. 24, n. 8, p. 643-650, ago. 2004.

KARAMI, A.; ROWLEY, J.; ANALOUI, F. Research and knowledge building in management studies: An analysis of methodological preferences. International Journal of Management, v. 23,1 jan. 2006.

KITCHENHAM, B. et al. Systematic literature reviews in software engineering - A systematic literature review. Information and Software Technology, v. 51, n. 1, p. 7-15, jan. 2009.

MARIMON, F.; MELÃO, N.; BASTIDA, R. Motivations and benefits of quality management systems in social services: mediation of the implementation process. Total Quality Management \& Business Excellence, p. 1-26, 7 jun. 2019.

MAULL, R.; BROWN, P.; CLIFFE, R. Organisational culture and quality improvement. International Journal of Operations \& Production Management, v. 21, n. 3, p. 302-326, mar. 2001. 
MILAKOVICH, M. E. Total Quality Management for Public Sector Productivity Improvement. Public Productivity \& Management Review, v. 14, n. 1, p. 19, 1990.

MOHAMMAD MOSADEGH RAD, A. The impact of organizational culture on the successful implementation of total quality management. The TQM Magazine, v. 18, n. 6, p. 606-625, 2006.

MOHANTY, R. P.; BEHERA, A. K. TQM in the service sector. Work Study, v. 45, n. 3, p. 13-17, jun. 1996.

PALADINI, E. P. Gestão Estratégica da Qualidade: Princípios, métodos e processos. 2a ed. São Paulo: Atlas S.A., 2009.

PANUWATWANICH, K.; NGUYEN, T. T. Influence of Organisational Culture on Total Quality Management Implementation and Firm Performance: Evidence from the Vietnamese Construction Industry. Management and Production Engineering Review, v. 8, n. 1, p. 515, 2017.

PRAJOGO, D. I.; MCDERMOTT, C. M. The relationship between total quality management practices and organizational culture. International Journal of Operations \& Production Management, v. 25, n. 11, p. 1101-1122, nov. 2005.

PUN, K.-F. Cultural influences on total quality management adoption in Chinese enterprises: An empirical study. Total Quality Management, v. 12, n. 3, p. 323-342, maio 2001.

RIBEIRO NETO, J. B. M.; TAVARES, J. C.; HOFFMANN, S. C. Sistemas de gestão integrados: qualidade, meio ambiente, responsabilidade social, segurança e saúde no trabalho. São Paulo: Editora SENAC, 2008.

SCHEIN, E. H. Organizational Culture and Leadership, 4th Edition. p. 457, 2010.

TARÍ, J. J. et al. Internalization of Quality Management Standards: A Literature Review. Engineering Management Journal, v. 32, n. 1, p. 46-60, 2 jan. 2020.

WAWAK, S.; ROGALA, P.; DAHLGAARD-PARK, S. M. Research trends in quality management in years 2000-2019. International Journal of Quality and Service Sciences, v. ahead-of-print, n. ahead-of-print, 4 maio 2020.

WILLAR, D.; TRIGUNARSYAH, B.; COFFEY, V. Organisational culture and quality management system implementation in Indonesian construction companies. Engineering, 
Construction and Architectural Management, v. 23, n. 2, p. 114-133, 2016.

ZGODAVOVA, K.; HUDEC, O.; PALFY, P. Culture of quality: insight into foreign organisations in Slovakia. Total Quality Management \& Business Excellence, v. 28, n. 910, p. 1054-1075, 2017.

ZHANG, D.; LINDERMAN, K.; SCHROEDER, R. G. The moderating role of contextual factors on quality management practices. Journal of Operations Management, v. 30, n. 1-2, p. 12-23, jan. 2012.

ZU, X.; ROBBINS, T. L.; FREDENDALL, L. D. Mapping the critical links between organizational culture and TQM/Six Sigma practices. International Journal of Production Economics, v. 123, n. 1, p. 86-106, jan. 2010. 